ARTICLE

\title{
SHOULD CHINA'S ECONOMIC POLICY BE RESISTED?
}

\author{
POSPELOV Valentin K. ${ }^{a}$; MIRONOVA Valentina N. ${ }^{b}$ CHUVAKHIN Petr I. ${ }^{c_{*}}$
}

a) Dr. of science (economics), professor, Financial University under the Russian Government, Moscow, Russia.

b) $P h D$ (economics), associate professor, Financial University under the Russian Government, Moscow, Russia.

c) Senior Lecturer, Department of International Law, Russian State University of Justice; Lecturer of the Department of International and Public Law, Financial University under the Government of the Russian Federation, Moscow, Russia. Corresponding Author (chuvakhin.petr@yandex.ru)

\section{PUBLISHED: 03/11/2021}

Accepted: $02 / 11 / 2021$

Submitted: $18 / 10 / 2021$

\section{COPYRIGHT NOTICE:}

(C) 2021 by authors. Licensee ERUDITUS. This article is an open access article distributed under the terms and conditions of the Creative Commons Attribution (CC BY) license (https://creativecommons.org/licenses/by/4.0/ ).

\section{CITE THIS PAPER:}

Pospelov Valentin. K.; Mironova Valentina N.; Chuvakhin Petr I. (2021). "Should China's Economic Policy be resisted?" Journal of World Economy: Transformations \& Transitions (JOWETT) 1(02):06. DOI: https://doi.org/10.52459/jowett1261121

\begin{abstract}
China's economic policies were transformed during the reform period that started in 1979, when the most populated country in the world adopted market-based reforms. Currently, China not only has grown to become the second largest and mid income economy in the world from one of the world's poorest countries, but also actively advances the free trade policy and fills the developing niches, although the latter has caused some concerns. The Chines active economic policy along with its economic and political strengthening in addition to the tensions with the United States rise the question whether the Chinese economic policy should be resisted? This paper analyses the different aspects of China's economic policy and intents to answer the question based on the importance of the Chinese role in the world economy and development while the public opinion toward China's economic strengthening has been considered as well.
\end{abstract}

\section{KEYWORDS}

China, Economic Policy, Public Opinion, USA, World Economy 


\section{INTRODUCTION}

China has done an outstanding job of shifting away from central planning while still dealing with economic issues. The fundamental motive for carrying out market-based changes in the late 1970s was to remove the inefficiency of central planning and give incentives for more efficient production. China has grown into a global economic giant in recent decades. Not only is it the second-biggest economy and the largest exporter of value, but it has invested quickly in development and international infrastructure as part of its Belt and Road Initiative. The public's views of the economic strength of China are largely favourable, especially in emerging economies, according to a recent Pew Research Centre survey (Silver L. et al., 2019). In this survey people frequently regard China's rising economy to be advantageous for their country and believe that China has a significant positive impact on the economic interests of their country. In another survey realized by Russian Levada Center (Levada, 2021), $75 \%$ of the participants have a positive view on China, and 14\% negative. However, a major part of participants consider that China has gained more respect in the world during the last decade.

Even if China's economic strengthening is usually considered as favourable in emerging countries, there are pockets of unhappiness. According to the mentioned survey, there is a division of feeling over China's growing military strength between those countries that support China's economic expansion. Rather, the rising military of China is viewed by most people as a threat to their own countries. The United States (US) and Canada have become more negative about China's growing military since 2007. Additionally, China's neighbours are more critical in general than the other countries assessed of Chinese military and economic progress. For example, in the Asia Pacific region, Chinese investment is more perceived as a potential risk since it gives Beijing too much authority over its economies. They are more willing than other countries to regard U.S. economic impact in their country positively. But China's perceptions are significantly more mixed to unfavourable in the case of developed countries. The countries with better records of human rights and a lower degree of corruption often detest China (Silver L. et al., 2019).

The Chinese economic influence is seen in a comparable or even somewhat more favourable way compared with the United States. Most people are positive about the bilateral economic links between their nation and China and the United States. Most of the countries also consider that the USA and China have an important or moderate impact on the economic conditions of their country. However, when it comes to judging that effect, more respondents say China has a favourable impact than the United States.

\section{Why should the US welcome the economic leadership of China}

\subsection{Promoting Chinese leadership free trade rhetoric}


China could seem an unexpected candidate in the Asia-Pacific region to lead the campaign for trade liberalization. Even though the economy continues to be full of government intervention, the United States officials and firms have expressed concerns about increasing regulatory obstacles and discrimination against international corporations, since the pro-market reforms had initially been adopted in the late 1970s. Thus, the United States and the European Union have refused to accord China market economy status for purposes of applying antidumping measures under their World Trade Organization (WTO) due to "protectionist backsliding and the continued state dominance of the Chinese economy" (Grabow, 2017).

China, on the other hand, may be beginning to see that lowering rather than expanding trade barriers is the way to go for its economic future. President Xi made a much-needed defence of free trade and globalization, especially during his speech at the World Economic Forum annual conference in Davos, Switzerland (CGTN, 2017). The president Xi said "We must remain committed by opening up and saying no to protectionism" among others to advance global free trade and investment, encouraging trade and investment liberalization and facilitation. He added that "Pursuing protectionism is like locking oneself in a dark room. While wind and rain may be kept outside, that dark room will also block light and air. No one will emerge as a winner in a trade war".

With regard to China's internal economy, Xi has committed to implement nebulous "structural supply transformation" measures to make it possible for the market to play a decisive role in allocated resources and many other proposals designed to entice investment from abroad. He said that an open door allows other nations to enter the Chinese market while enabling China to interact with the rest of the globe.

Such a phrase by the Chinese leadership may have sought to pacify global onlookers while planning a completely different approach at home. Nonetheless, there are reasons for optimism. The start of exploratory negotiations between China and Canada regarding the possible FTA in March 2017 is a promising indication, signalling that both Beijing is ready to open up the economy and that Ottawa is confident that Beijing is genuine about its goal for greater external business and economic openness (Zhang et al., 2019).

The Chinese and New Zealand governments on January 2021 have signed a deal to upgrade Their Free Trade Agreement (FTA). The negotiations about this upgrade were started from 2014. This appears to be another sign of China's commitment. In the recent years China is actively expanding its economic relations with different countries. Over the last five years, China has inked, in addition to New Zealand, with Australia, South Korea, Switzerland and Iceland, and currently negotiates with South Korea and Japan a trilateral FTA. However, according to Kazushi Shimizu (2021) the wider FTA for East Asia as a whole was not established and the JapanChina-Korea FTA was also not established. With regard to the wider East Asian FTA, Japan proposed the Comprehensive Economic Partnership in East Asia (CEPEA) including 16 members of the EAS, and China 
proposed the East Asian regional Free Trade Area (EAFTA) including 13 members of APT. However, these agreements were not concluded.

\subsection{The Regional Comprehensive Economic Partnership (RCEP)}

China's foremost international trade initiative is its participation in the Regional Comprehensive Economic Partnership (RCEP), which is usually considered a China-led initiative, in spites of its ASEAN beginnings. It includes the 10 members of the Association of Southeast Asian Nations (ASEAN) and the six nations with which it has existing free trade agreements (China, Australia, India, South Korea, Japan, and New Zealand). The RCEP is, despite its ASEAN roots, widely described as a China-driven effort. That, in turn, has led many observers to characterize the RCEP as a Chinese-led alternative- a rival- to the Trans-Pacific Partnership (TPP) and a potential economic threat to the United States (Grabow, 2017). However, that characterization is roundly rejected by the governments that are party to both the RCEP and the TPP and that see membership in both as their preference. Nations participants to the RCEP and the TPP, however, that regard membership as a priority, are totally opposed to this category.

The RCEP should consider what it is: a trade agreement that reduces trade barriers, supports economic growth and enables nations, especially those with the Unites States of America (USA), to join other agreements. After the USA withdrew from the TPP (Trans Pacific Partnership), the RCEP would give the attempts to liberalize regional trade a much-needed impetus. After 8 years of negotiations, RCEP was signed on 15 November 2020. RCEP is the largest free trade agreement in history, involving about $30 \%$ of global gross domestic product and about the same proportion of the world's population (Yasuyuki, 2020). It will enter into force once ratified by at least six ASEAN economies and three non-ASEAN signatories, a process that will take months to start and years to complete. The Asian Development Bank has suggested that the potential benefits of regional trade agreements and real income increases within RCEP in 2030 will be $\$ 165$ billion, while this parameter for rest of the world will be \$21 billion (AEIR, 2021).

Frenkel and Ngo (2021) believe that the RCEP Agreement may have a negative impact on the competitiveness of European companies and on the foreign direct investment flows to member states. Additionally, considering the importance of EU standards in international trade, this raises the question of how the EU should respond to the creation of the RCEP space. According to these scientists, there are several strategic options for the EU, but none of them is ideal or easy to implement, however, the growing importance of the Asia-Pacific region in the world economy suggests a closer Alliance with the RCEP countries.

The former U.S. President Barack Obama and others have warned that "countries like China," if the RCEP succeeds and the TPP fails, will be able "in the 21 st century to set the road rules for trade" (Obama, 2017). This statement, according to Grabow $(2017)$ is commonly interpreted as an oblique allusion to the Free 
Trade Area of the Asia Pacific (FTAAP) or other broader initiatives to advance trade in the Asia-Pacific region, and it assumes that either the RCEP or the TPP will be used as the starting point for such efforts.

On the other hand, there are at least two issues with this style of thinking. First, the concept is not dead despite the US pull-out from the TPP; Japan and others are attempting to join forces with the remaining TPP11 countries. Second, it is still unclear why the RCEP will be a model or possible endpoint for an FTAAP or similar pact even when the TPP is removed. Several countries have shown interest in expanding agreements on higher standards, including Japan, New Zealand, Australia and the Pacific Alliance and their wishes would almost certainly be represented in the negotiation table.

The RCEP may be a point of departure for future negotiations, but it can be seen no way. Furthermore, pursuing both the RCEP and the TPP at the same time could be beneficial to the region's free trade advancement. According to a study by the Center for Strategic and International Studies (CSIS) in July 2017, a competition between the two agreements has the potential to promote virtuous competition for trade liberalization and needed reform in China (Green, et al, 2017).

\subsection{China's Infrastructure Push}

Aside from expressing interest in leading regional trade liberalization initiatives, in the development of infrastructural connections needed for growing trade and integration in Asia, Chinese government has also taken the lead. To accomplish so, China has proposed the Asian Infrastructure Investment Bank (AIIB) and the Belt \& Road Initiative (BRI), both being proposed in 2013.In response to the demand from China for finance to overcome a deficit in infrastructure in the area, AIIB was founded. A key purpose of the bank is to meet the "daunting demands for infrastructure throughout Asia".

As it's highlighted by Bora Ly (2021), emerging economies have long sought to be more included in the World Bank (WB) and the International Monetary Fund (IMF), but the voice change in these organizations was sluggish and constrained and the Western domination of the WB and the major regional Multilateral Development Banks (MDBs) has influenced multilateral development financing goals and practices. As this researcher mentions, over decades, the WB has ignored infrastructure financing for poverty alleviation and "good governance." It also made lending conditional, such as the IMF, leveraging development finance to promote borrowing nations' policy reforms. It also evolved into a vast, bloated, and inefficient bureaucracy. The founders of the New Development Bank (NDB) and AIIB contended that the new institutions should correct such errors. The new MDBs would provide more excellent representation for developing nations, focus on infrastructure development, eliminate lending policies, and enhance efficiency. 
Another Chinese initiative, BRI, is aimed at reviving old trade routes between China and Eurasia, and it represents a set of infrastructure projects designed to build and improve links between road, energy, rail, and maritime transport. It comprises the Silk Road Economic Belt and the Maritime Silk Road. Nevertheless, China's goals of these projects go beyond those proclaimed to include increased regional influence and demand in the Chinese economy for the absorption of spare capacity. As indicates Grabow (2017), whether those goals will be realized is unclear, but neither should be viewed as aggressive or otherwise problematic from a Unites States perspective; If China succeeds in expanding its influence in Central Asia, it is likely to do so at the expense of Russia, a trade many U.S. policymakers would likely be perfectly willing to make.

In the United States, businesses, consumers, and employees have no direct financial risk for BRI or the AIIB but will profit if the programs manage to foster more commerce and development. While the judgment on the success of the projects supported by China is still over, US officials are cautiously optimistic. The Belt \& Road Initiative is generally considered positive and a great way for collaboration between China and its neighbours. According to the opinion of Kevin Sneader (McKinsey, 2016), the BRI "has the potential to be perhaps the world's largest platform for regional collaboration." In fact, while China cannot follow the preferred U.S. playbook, policymakers should recognize that its actions could aid the USA to achieve its bigger goals of peace and development in Asia. As it's highlighted by William J. Burns (2020) "preventing China's rise is beyond America's capacity, and our economies are too entangled to decouple. The U.S. can, however, shape the environment into which China rises, taking advantage of the web of allies and partners across the IndoPacific — from Japan and South Korea to a rising India — who worry about China's ascendance. That will require working with them - and engaging Chinese leadership directly — to bound rivalry with Beijing, define the terms for coexistence, prevent competition from becoming a collision, and preserve space for cooperation on global challenges".

\section{International opinions on China, tinted by the economic approach}

Worldwide views on China are varied. An average of $40 \%$ of persons in the 34 countries surveyed had China's positive impression, and $41 \%$ had a negative attitude. In all the countries concerned, however, the views varied dramatically, as they are 71\% high in Russia and 14\% low in Japan (Silver L. et al., 2019). Statistical modelling results show that Chinese perceptions are linked to these economic attitudes amongst a selection of 15 countries asking questions about global economic involvement in general as well as Chinese investment in specific.

The economic strength of China is a factor in the country's overall appraisals. Mainly, the positive perception of China is based on maintaining a good economic relation with a superpower and consequently the 
benefits for a country, however, the negative perception arises from the predominance of import from China in the bilateral trade balances.

China's favourable views are also connected with increased economic happiness and openness to global investment. Those satisfied with their own local economy are more inclined to have positive opinions of China. Those who believe it is good to buy domestic firms in their own country by foreign companies or to develop national firms in their own country are also more advantageous to China.

According to Giles Mohan (2020) "China's rise as a development actor is being organized through twisted and overlapping territories... This multiplicity of territorial strategies is necessary given that China is seeking to both align with and change the existing geopolitical structures while also creating markets for Chinese goods and services. Lots of work is going into this territory making that is material, political and ideological. Crucially, despite working through different scales and across networks, the Chinese state and the regimes of other countries remain central to these forms of territory. The key is how state power works in consort with informal political and geoeconomic structures and how these are organized in networked and enclaved ways."

An average of 66 percent of 17 nations have favourable economic links between their country and China. Likewise, the US' current economic relations with its countries are good to a big proportion of the people (a median of 64 percent). In actuality, the majority of the countries surveyed in the majority felt that their current relations are positive with each of the superpowers. For example, $85 \%$ of Australians say that America's business relationships with Australia are in good shape, while $80 \%$ believe that China's relations are in good shape (Silver L. et al., 2019).

People in a number of countries will likely look positively at existing economic relations with one superpower while looking negative on the other. Canada is now in the grip of trade challenges with China, with existing relationships with China $20 \%$ lower than with the United States, even as trade negotiations over the agreement between the United States, Mexico, and Canada (USMCA) continue on. Countries on the periphery of China, such as Japan, South Korea and Philippines view current US economic relations significantly better than China's. The opposite is true in certain nations in the North Africa and Middle East. The economic relationships with the United States are just good for $42 \%$ of Lebanese compared to $82 \%$ for China.

Based on the above-mentioned survey (Silver L. et al., 2019), whether the United States or China has an advantageous or unfavourable impact on the economic conditions of each country, public opinion is, however, somewhat more friendly to China. Average $48 \%$ think China has a positive influence on economic conditions in their country, compared with $42 \%$ who think the same as in the United States. More individuals in Sub Saharan Africa, Latin America, and the North Africa and Middle East even in places where the contributions from the two countries are considered positively as generally, are positive about China's influence 
than the United States. For example, $69 \%$ of Nigerians say that the economic influence of China is good in Nigeria, while $49 \%$ believe the same thing in the United States. On the other hand, most Asia-Pacific countries believe that the economic effect of the US is higher than that of China.

However, regarding the trade discrepancies between the Unites States and China, researchers believe that the tension in the bilateral relation can affect the US interests as well. Although the USA has legitimate reasons for pressuring China, the country is also a convenient target for domestic grievances. Although China would prefer to return to the status quo, it will resist and counterattack US actions to both prevent economic decline and showcase power to domestic and foreign audiences (Boylan, et al, 2020).

As suggests Peters (2021), rather than the 'containment' strategy ringing China with military bases around the periphery of the South China Sea, the US should recognize certain civilizational competing claims and work with China to enhance economic, educational and cultural links in Asia and to promote strategic partnerships. Perhaps most importantly the strategic US-China partnership would focus on rebuilding successful global institutions based on the reform of the existing design along with the development of new international trading, educational and cultural partnerships, and will help the transformation of the liberal world order to include greater involvement of BRIC countries, of BRI member countries, of ASEAN countries, and a greater recognition of South-South multilateralism.

\section{CONCLUSION}

China's ascent has sparked widespread concern about the country's expanding economic power, reflected in the public opinion as well, especially in the United States, the EU, and countries with deficit in their bilateral trade balances. Furthermore, the strengthening of Chinese economy is associated with possible military threats in the China's neighbour countries. From the other side, the China's economic policy of advancing the infrastructural and development projects along with the promotion of the free trade agreements increases the competitiveness in Asia. Although the RCEP is not a free trade concept for everyone, this is a first step towards a completely liberalized Asia Pacific area which will reduce trade barriers at a time when greater efforts are likely to decrease. Likewise, Chinese verbal free trade support should be praised. Despite some analysts concluded that China international economic schemes, such as AIIB, BRI and RCEP, constitute a threat to US interests or require more vigilance, the prospects that the world's second largest economy will start to share some leadership responsibilities in promoting free trade and deeper economic integration should at least be considered, rather merely reflectively expressing mistrust of or antagonism to China's actions. 
FUNDING: The authors did not receive any external funding.

CONFLICT OF INTEREST: The authors declare no conflicts of interest.

\section{REFERENCES}

1. AEIR, (2021). Asian Economic Integration Report 2021. Making digital platforms work for Asia and the Pacific. February 2021. Asian Development Bank. DOI: http://dx.doi.org/10.22617/TCS210048$\underline{2}$

2. Bora Ly; John Kwame Boateng (Reviewing editor) (2021). "China Quest for global governance overhaul", Cogent Social Sciences, 7:1, DOI: 10.1080/23311886.2021.1932031

3. Boylan, B.M.; McBeath, J.; Wang, B. (2021). "US-China Relations: Nationalism, the Trade War, and COVID-19". Fudan J. Hum. Soc. Sci. 14, 23-40 . https://doi.org/10.1007/s40647-020-00302-6

4. Burns William J. (2020). "The United States Needs a New Foreign Policy", Carnegie Endowment for International Peace, 14.07.2020. Available at: https://carnegieendowment.org/2020/07/14/unitedstates-needs-new-foreign-policy-pub-82295

5. CGTN, (2017). Full Text of Xi Jinping keynote at the World Economic Forum. Available at: https://america.cgtn.com/2017/01/17/full-text-of-xi-jinping-keynote-at-the-world-economicforum

6. Frenkel, M.; Ngo, T. Das (2021). "RCEP-Abkommen und dessen Bedeutung für die EU". Wirtschaftsdienst 101, 432-438 (2021). https://doi.org/10.1007/s10273-021-2938-X

7. Grabow, Colin (2017). "Responsible Stakeholders: Why the United States Should Welcome China's Economic Leadership". Cato Institute Policy Analysis, (821). Available at: http://wwwghanapolitics.blogspot.com/2017/10/cato-institutecolin-crabow-responsible.html

8. Green, Michael J.; Bush, Richard C.; Rapp-Hooper, Mira (2017). "Joint US-China Think Tank Project on the Future of US-China Relations: An American Perspective", Center for Strategic and International Studies, July 2017, Available at: https://csis-website-prod.s3.amazonaws.com/s3fspublic/publication/170705 US Report.pdf?V2dPire5xBHP1Sp7nx4df9qrtYbs5F4Y.

9. Kazushi Shimizu (2021). "The ASEAN Economic Community and the RCEP in the world economy", Journal of Contemporary East Asia Studies, 10:1, 1-23, DOI: 10.1080/24761028.2021.1907881

10. Levada (2021). Russian-Chinese Interrelations, Survey by Analytical Center Levada, 30.03.2021. Available at: https://www.levada.ru/2021/03/30/rossijsko-kitajskie-otnosheniya/ 
11. McKinsey, (2016) Joe Ngai, Kevin Sneader, and Cecilia Ma Zecha,"China’s One Belt, One Road: Will It Reshape Global Trade?” McKinsey\& Company, Hong Kong, July 2016. Available at: https://www.mckinsey.com/featured-insights/china/chinas-one-belt-one-road-will-it-reshapeglobal-trade.

12. Mohan Giles (2020). "Below the Belt? Territory and Development in China's International Rise" Development and Change 52(1): 54-75. DOI: 10.1111/dech.12612

13. Obama Barack, (2016). "The TPP Would Let America, Not China, Lead the Way on Global Trade," Washington Post, May 2, 2016, https://www.washingtonpost.com/opinions/president-obama-the-tppwould-let-america-not-china-lead-the-way-on-global-trade/2016/05/02/680540e4-0fd0-11e6-93ae$\underline{50921721165 d \text { story.html?utm term }=.037 \mathrm{bc} 3 \mathrm{a} \text { acb05 }}$

14. Peters, Michael A. (2021). "US-China relations: Towards strategic partnerships", Educational Philosophy and Theory, DOI: 10.1080/00131857.2021.1937994

15. Silver, L.; Devlin, K.; Huang, C.; Pew Research Center. (2019). "China's Economic Growth Mostly Welcomed in Emerging Markets, But Neighbors Wary of Its Influence: US Still Seen as World's Leading Economic Power". Pew Research Center. Available at: https://www.pewresearch.org/global/2019/12/05/chinas-economic-growth-mostly-welcomed-inemerging-markets-but-neighbors-wary-of-its-influence/

16. Yasuyuki Sawada, (2020). "The Regional Comprehensive Economic Partnership will likely shape the future of trade in Asia and beyond". China Daily Global 18.12.2020. Available at: http://www.chinadaily.com.cn/a/202012/18/WS5fdbecb9a31024ad0ba9c821.html

17. Zhang, D.; Lei, L.; Ji, Q.; Kutan, A. M. (2019). "Economic policy uncertainty in the US and China and their impact on the global markets". Economic Modelling, 79, 47-56.

DOI: https://doi.org/10.1016/j.econmod.2018.09.028 